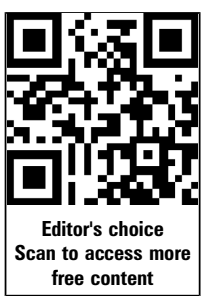

- Additional material is published online only. To view please visit the journal online (http://dx.doi.org/10.1136/ bjsports-2014-094162).

${ }^{1}$ Department of Physical Therapy, Universitat Internacional de Catalunya, Barcelona, Spain

${ }^{2}$ Department of Occupational Therapy and Physiotherapy, Aalborg University Hospital, Aalborg, Denmark

${ }^{3}$ Department of Health Science and Technology, Center for Sensory-Motor Interaction, Aalborg University, Aalborg, Denmark

${ }^{4}$ Iberoamerican Cochrane Centre, Sant Pau Biomedical Research Institute, Barcelona, Spain

${ }^{5}$ Faculty of Health Sciences, Sports Orthopedic Research Center, Arthroscopic Centre Amager, Amager-Hvidovre Hospital, University of Copenhagen, Copenhagen, Denmark

${ }^{6}$ Physical Medicine and Rehabilitation-Copenhagen (PMR-C), Amager-Hvidovre Hospital, Copenhagen University Hospital, Copenhagen, Denmark

Correspondence to E Esteve, Department of Physical Therapy, Universitat Internacional de Catalunya, Josep Trueta s/n, Sant Cugat del Vallés, Barcelona 08195 Spain; ernest.esteve@uic.es

Accepted 26 January 2015 Published Online First 24 February 2015

CrossMark

To cite: Esteve $\mathrm{E}$, Rathleff MS, Bagur-

Calafat C, et al. Br J Sports Med 2015:49:785-791.

\title{
Prevention of groin injuries in sports: a systematic review with meta-analysis of randomised controlled trials
}

\author{
E Esteve, ${ }^{1}$ M S Rathleff, ${ }^{2,3}$ C Bagur-Calafat, ${ }^{1}$ G Urrútia, ${ }^{4} \mathrm{~K}$ Thorborg ${ }^{5,6}$
}

ABSTRACT

Background/aim Groin injuries are common in football and ice hockey, and previous groin injury is a strong risk factor for future groin injuries, which calls for primary prevention. The aim of this systematic review was to evaluate the effect of specific groin-injury prevention programmes in sports.

Methods A comprehensive search was performed in May 2014 yielding 1747 potentially relevant references. Two independent assessors evaluated randomised controlled trials for inclusion, extracted data and performed quality assessments using Cochrane's risk of bias tool. Quantitative analyses were performed in Review Manager 5.3.

Results Seven trials were included: six on football players (four male and two female populations) and one on male handball players. In total there were 4191 participants with a total of 157 injuries. The primary analysis, including all participants, did not show a significant reduction in the number of groin injuries after completing a groin injury prevention programme (relative risk (RR) $0.81 ; 95 \% \mathrm{Cl} 0.60$ to 1.09). Subgroup analysis based on type of sports, gender and type of prevention programme showed similar non-significant estimates with RR ranging from 0.48 to 0.81 .

Conclusion Meta-analysis revealed a potential clinically meaningful groin injury reduction of $19 \%$, even though no statistical significant reduction in sport-related groin injuries could be documented.

Trial registration PROSPERO registration ID CRD42014009614.

\section{INTRODUCTION}

Groin injuries represent $5-10 \%$ of all sports injuries. ${ }^{1-4}$ They are highly prevalent in sports requiring kicking, high-speed direction changes and/or skating motions. In these sports groin injuries account for $10-23 \%$ of all injuries. ${ }^{5-10}$ In football and ice hockey, groin injuries have an incidence of 1.1/1000 $\mathrm{h}$ exposure ${ }^{9}$ and 1.3/1000 players exposure, ${ }^{11}$ respectively, during a regular season. The hip adductors are the most commonly injured muscle group in sports-related groin injuries. ${ }^{9-12}$ This is likely due to the eccentric forces stressing the muscle-tendinous complex during side-to-side cutting, kicking and powerful skating. ${ }^{13}{ }^{14}$ Groin injuries seem to be less frequent in female compared with male football players. ${ }^{4}{ }^{15}{ }^{16}$ In men, more than $50 \%$ of groin injuries are classified as moderate or severe at elite level, ${ }^{9}{ }^{17}$ resulting in substantial periods of absence from football play. Recent studies showed that the prevalence of hip and groin pain during a season can be up to
$70 \%,{ }^{18} 19$ suggesting that time-loss injury incidences represent the tip of the injury iceberg, with many athletes often continuing to play, but with pain. ${ }^{20}$

A previous history of groin injury ${ }^{11} 1721$ or hip adduction strength deficits ${ }^{22-24}$ has been identified as a significant risk factor for a new groin injury. Groin injury prevention consists of active strength and coordination exercises, with emphasis on the adductor and abdominal muscles, ${ }^{22-26}$ as these are modifiable risk factors. ${ }^{21} 27$ An exercise programme including strengthening and coordination exercises for adductors and muscles around the pelvis has also been demonstrated to be effective in treatment of long-standing groin pain. ${ }^{28}$ Similarly, a preseason adductor strengthening programme appeared to reduce the incidence of adductor strains in a group of professional ice hockey players. ${ }^{29}$ Therefore, it seems reasonable to assume that groin injuries in sports may be prevented through specific prevention strategies targeting relevant risk factors and mechanism of injury despite the fact that this seems to remain unproven in randomised controlled trials.

Preventing groin injuries in sports such as football and ice hockey is of great importance, since these injuries induce substantial disability and loss of playing time, injury-related costs ${ }^{30}$ and an increased risk of reinjury ${ }^{9} 17 \quad 21$ and chronicity. ${ }^{9} \quad 28 \quad 31$ However, to the best of our knowledge, no systematic review or meta-analysis on the prevention of groin injuries in sports has been published to date. The aim of this systematic review was to evaluate the effect of specific groin-injury prevention programmes in sports.

\section{METHODS}

Search strategy

EMBASE, MEDLINE, SPORTDiscus, LILACS, PEDro and Cochrane Central Register of Controlled Trials were electronically searched from January 1970 to May 2014. A hand-search of the reference lists of relevant articles was also conducted for other potential relevant references. A review protocol was developed according to the PRISMA $^{32}$ recommendations and published in the PROSPERO database (http://www.crd.york.ac.uk/ PROSPERO/display_record.asp? ID $=$ CRD4201400 9614). The search strategy was constructed and followed the PICO approach (Population, Intervention and Outcome). Search terms were mapped to each component of the PICO and connected with Boolean operators adapted to the individual databases. When possible, filters for randomised controlled trials were applied. The 
complete search strategy can be seen in online supplementary web-appendix 1.

\section{Inclusion and exclusion criteria}

Data from randomised and cluster-randomised controlled trials were included. We included studies with athletes that reported the incidence of groin injuries as an outcome. Only full text trials in English were considered. Studies conducted in army recruits were excluded.

\section{Review process}

Titles and abstracts identified in the search were downloaded into EndNote X7 (Thomson Reuters, Carlsbad, California, USA); cross references and duplicates were deleted. All publications potentially relevant for inclusion were independently assessed for inclusion by two reviewers (EE and KT) and full texts were obtained, if necessary. Any discrepancies were resolved during a consensus meeting, and a third reviewer was available (CB), if needed.

\section{Data extraction}

Two reviewers (EE and KT) independently extracted data using a specifically designed standardised form. General study information, participants and intervention characteristics, compliance, withdrawals and outcome measures were extracted. If data were not available from tables or the result section, the authors were contacted. If the authors did not have access to their data, data on outcome were extracted from figures and graphs. Whenever possible, results from the intention-to-treat population were used.

\section{Assessment and risk of bias}

The studies included were assessed for the risk of bias by two independent raters (KT and EE), with any disagreements resolved by consultation with a third party (GU). An assessment of the methodological quality was not performed, as no evidence for such appraisals and judgments exists and therefore can be misleading when interpreting the results. ${ }^{33}$ The use of quality scales and summary scores is considered problematic, due to considerable variations between items and dimensions in scales covered, with little evidence relating to the internal validity of these assessments. ${ }^{34}$ The risk of bias assessment was done using the Cochrane Collaboration's tool for assessing risk of bias in randomised trials. ${ }^{33}$ The trial was evaluated across six domains of bias, including one or more items that were appraised in two parts. First, the relevant trial characteristics related to the item were summarised. Second, each bias domain was judged as high or low risk of bias, according to its possible effect on the results of the trial. When the possible effect was unknown or insufficient detail was reported, the item was judged as unclear. When we assessed risk of bias in clusterrandomised trials, particular biases were included in the 'other bias' domain, as assessing risk of bias in cluster-randomised trials is recommended in the Cochrane Handbook for Systematic Review of Interventions, V.5.1 (Part 3: 16.3.2). ${ }^{33}$

\section{Study analysis}

Relative risk (RR) and 95\% CIs were estimated as relative effect size using the extracted data. In the analysis of cluster randomised controlled trials, we used the intracluster correlations coefficient (ICC) from the trials to adjust for a potential cluster effect. If the authors did not report the ICC we used the ICC from similar trials.

\section{Data synthesis}

Review Manager V.5.3 (Copenhagen: The Nordic Cochrane Centre, The Cochrane Collaboration) was used to calculate RR. A forest plot was used to allow easy visual comparisons between studies. The level of statistical heterogeneity for pooled data was established using the $\chi^{2}$ and $\mathrm{I}^{2}$ statistics. The $\chi^{2}$ and $\mathrm{I}^{2}$ statistics describe heterogeneity or homogeneity of the comparisons with $\mathrm{p}<0.05$, indicating a significant heterogeneity. ${ }^{35} \mathrm{~A}$ fixed-effect model was used when studies were statistically homogeneous. The Mantel-Haenszel ${ }^{36} 37$ method was selected as default option. This method has been recommended when there are low event rates. ${ }^{33}$ If studies were statistically heterogeneous, the Mantel-Haenszel ${ }^{36} \quad 37$ random-effects model was applied. Sensitivity analyses were planned on the primary outcome, focusing on methodological quality and risk of bias assessment. We considered aspects such as: allocation concealment, outcome assessor blinding, incomplete data, selective reporting and other bias.

\section{Analysis of subgroups or subsets}

Possible interactions between groups were evaluated using the technique outlined by Altman and Bland. ${ }^{38}$ Relations sustained on type of sports, gender and type of preventive programmes were assessed.

\section{RESULTS}

\section{Search results}

The initial search identified 1747 unique references (figure 1). After exclusion by title and abstract, 33 were read in full text. From the 33 articles, 26 were excluded. The most common reason for exclusion (15 studies) was that studies did not report the incidence of groin injuries in isolation. Eleven studies were not RCTs and were therefore also excluded. Finally, seven studies were included.

\section{Description of studies}

The most relevant characteristics of the seven included studies are summarised in table 1 . For detailed information on study design, participants, exposure and statistics see online supplementary web-appendix 2. Six studies were cluster-randomised controlled trials, where teams or clubs were the unit of randomisation, while one study performed randomisation at the individual level. In total, the included studies involved 4648 participants. Three studies reported exposure data. ${ }^{39-41}$ Among cluster-randomised trials, one study was adjusted for clustering effects, reporting an ICC value equal to zero. ${ }^{42}$ Compliance reports were not specified according to prescribed or optimal dosage (see table 1) and only three studies reported intention-to-treat data.

Time-loss groin injury definition was used in six of the seven included studies, ${ }^{39-41} 43-45$ while the last study used time-loss as well as medical-attention definitions. ${ }^{42}$ The authors of two studies were contacted to provide extra data for exposure, age of participants and number of groin injuries. ${ }^{42}$ Data from van Beijsterveldt et $a l^{43}$ were obtained, but exposure data from Hölmich et $a l^{42}$ were not available. Results of the risk of bias assessment are presented in meta-analysis figures (figure 2A-F). Specific justification for each assessment is included in online supplementary web-appendix 2 .

\section{Total estimate}

In total, 4191 players were included in the primary analysis. For the primary outcome, number of groin injuries in the control 
Figure 1 Flow chart of included studies.

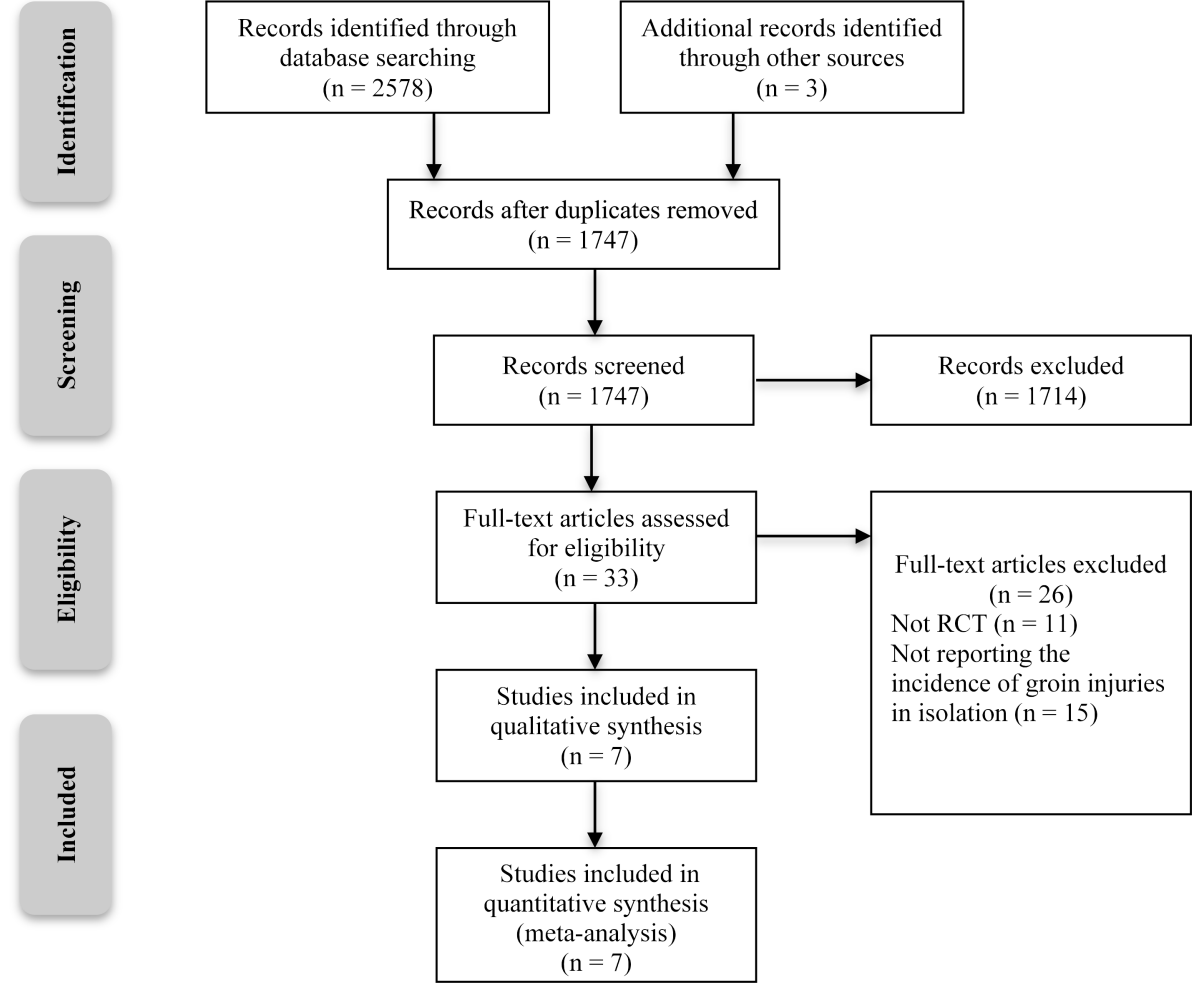

group versus the intervention group, the effect estimates based on 157 injuries (figure 2A), was RR 0.81 (95\% CI 0.60 to 1.09 ; $\left.\mathrm{I}^{2}=7 \% \chi^{2} \mathrm{p}=0.37\right)$.

\section{Type of sport analysis}

The study on handball players did not report any groin injuries. ${ }^{45}$ The subgroup analysis on type of sport (figure $2 \mathrm{~B}$ ), therefore, included the remaining six football studies, ${ }^{39-44}$ which showed an effect estimate of RR 0.81 (95\% CI 0.60 to 1.09; $\left.\mathrm{I}^{2}=7 \% \chi^{2} \mathrm{p}=0.37\right)$.

\section{Gender analyses}

A gender specific subgroup analysis of two football studies conducted among female players, including active exercise programmes (figure 2C), ${ }^{41}{ }^{44}$ showed an estimate of RR 0.48 (95\% CI 0.20 to $1.13 ; \mathrm{I}^{2}=46 \% \chi^{2} \mathrm{p}=0.17$ ). Pooled data from the three football studies, including active exercise programmes, performed among men (figure 2D), ${ }^{404} 43$ showed an effect estimate of RR 0.84 (95\% CI 0.60 to $1.18 ; \mathrm{I}^{2}=0 \% \chi^{2} \mathrm{p}=0.57$ ).

\section{Type of preventive programme analyses}

An active adductor strength programme was tested in two studies, ${ }^{40} 42$ with a pooled effect estimate (figure $2 \mathrm{E}$ ) of RR 0.78 ( $95 \%$ CI 0.49 to $1.25 ; \mathrm{I}^{2}=0 \% \chi^{2} \mathrm{p}=0.34$ ). 'The 11 ' preventive programme (figure $2 \mathrm{~F}$ ) was tested in two trials, ${ }^{41} 43$ with a pooled effect estimate of RR 0.68 (95\% CI 0.40 to 1.14 ; $\left.\mathrm{I}^{2}=55 \% \chi^{2} \mathrm{p}=0.13\right)$.

\section{DISCUSSION}

The aim of this systematic review was to evaluate the effect of specific groin-injury prevention programmes in sports. No statistical significant reduction in sport-related groin injuries could be documented. Meta-analysis revealed a potential clinically meaningful groin injury reduction of $19 \%$ (RR 0.81 ; $95 \%$ CI 0.60 to 1.09 ).

\section{Subgroup analyses}

Football

An identical non-significant estimate was identified in the subgroup analysis in football players (RR 0.81 ; 95\% CI 0.60 to 1.09 ). Five of the six studies conducted on football players assessed the efficacy of active exercise strategies to prevent groin injuries. ${ }^{40-44}$ The potential effect of such type of intervention was previously documented in a prospective study of ice hockey players at high risk, ${ }^{29}$ but has never been tested in a randomised controlled trial. Nevertheless, in a randomised trial an active strengthening programme was very effective in the treatment of long-standing adductor-related groin pain in athletes. ${ }^{28}$ Moreover, the effect of this therapeutic intervention was found to be long-lasting, ${ }^{46}$ suggesting a possible secondary preventive effect.

Among the six studies conducted on football players, two studies ${ }^{40} 41$ reported limited compliance. A deterioration of compliance during the season has been shown previously in football studies, which may affect the results, as higher compliance allows for better results in preventive interventions. ${ }^{47} 48$ Compliance was very low in one study ${ }^{40}$ of a home-prevention programme, where less than $20 \%$ of the participants completed 20 or more of the 30 planned sessions. It is important to consider that an active programme under supervision usually gives higher compliance and more benefits in strength and physical conditioning. 49

\section{Sex}

The sex-specific subgroup analysis, including studies looking at active exercise programmes, showed a non-significant risk reduction of $52 \%$ among female football players (RR $0.48 ; 95 \% \mathrm{CI}$ 0.20 to 1.13$)$. In comparison, the analysis including male football players showed a non-significant risk reduction of $16 \%$ (RR 0.84 ; $95 \%$ CI 0.60 to 1.18 ). Although non-statistical, the apparent difference in estimates is interesting. We speculate that if this difference exists it could be because these programmes are 
Table 1 Characteristics of the included studies

\begin{tabular}{|c|c|c|c|c|c|c|c|}
\hline Study & Population & Intervention & $\begin{array}{l}\text { Completion } \\
\text { (players) }\end{array}$ & Compliance & Follow-up & $\begin{array}{l}\text { Number of } \\
\text { groin injuries }\end{array}$ & Conclusion \\
\hline Arnason et a $\beta^{39}$ & $\begin{array}{l}\text { Football, elite, male } \\
\text { (age not specified) }\end{array}$ & $\begin{array}{l}15 \text { min presentation and video-based awareness. } 2 \mathrm{~h} \\
\text { workshop in the respective clubs. Once only } \\
\text { intervention }\end{array}$ & $\begin{array}{l}\text { Intervention } 127 \\
\text { Control } 144\end{array}$ & Not reported & $\begin{array}{l}1 \text { season, } \\
4 \text { months }\end{array}$ & $\begin{array}{l}\text { Intervention } 7 \\
\text { Control } 6\end{array}$ & $\begin{array}{l}\text { No significant difference was } \\
\text { observed in the number of groin } \\
\text { injuries }\left(\chi^{2}: z=0.50\right)\end{array}$ \\
\hline $\begin{array}{l}\text { Van Beijsterveldt } \\
\text { et } a^{43 *}\end{array}$ & $\begin{array}{l}\text { Football, amateur, } \\
\text { male }(18-40)\end{array}$ & $\begin{array}{l}\text { 'The } 11 \text { ': } 10 \text { exercises for core stability, eccentric } \\
\text { training of the thigh muscles, proprioception, } \\
\text { dynamic stabilisation and plyometric with straight } \\
\text { alignment. } 10-15 \text { min warm-up programme during } \\
\text { regular practice }\end{array}$ & $\begin{array}{l}\text { Intervention } 223 \\
\text { Control } 233\end{array}$ & $\begin{array}{l}\text { 'The } 11 \text { ' was performed on an } \\
\text { average of } 1.3 \text { per week of two per } \\
\text { week that were prescribed, at least }\end{array}$ & $\begin{array}{l}1 \text { season, } \\
9 \text { months }\end{array}$ & $\begin{array}{l}\text { Intervention } 20 \\
\text { Control } 23\end{array}$ & Not reported for groin injury \\
\hline Engebretsen et a $\mathrm{l}^{40} \dagger$ & $\begin{array}{l}\text { Football, elite, male } \\
\text { (age not specified) }\end{array}$ & $\begin{array}{l}\text { Isometric adductor muscles exercises, transverse } \\
\text { abdominal training, sideways jumping, sliding and } \\
\text { diagonal walking. } 15 \text { min training session at home }\end{array}$ & $\begin{array}{l}\text { Intervention } 62 \\
\text { Control } 98\end{array}$ & $\begin{array}{l}19,4 \% \text { of players completing } 20 \\
\text { sessions or more out of how many } \\
\text { prescribed }\end{array}$ & $\begin{array}{l}1 \text { season } \\
\text { including } \\
10 \text {-week } \\
\text { preseason }\end{array}$ & $\begin{array}{l}\text { Intervention } 11 \\
\text { Control } 16\end{array}$ & $\begin{array}{l}\text { No significant difference was } \\
\text { observed in the number of groin } \\
\text { injuries (RR=1.18; } 95 \% \mathrm{Cl} 0.55 \\
\text { to } 2.54 \text { ) }\end{array}$ \\
\hline Holmich et $a l^{42 *}$ & $\begin{array}{l}\text { Football, amateur, } \\
\text { male (18-42.4) }\end{array}$ & $\begin{array}{l}\text { Isometric and eccentric hip adductors strengthening, } \\
\text { abdominal and hip flexors training, one leg } \\
\text { coordination and stretching of iliopsoas muscle. } \\
13 \text { min as an integrated part of regular warm-up }\end{array}$ & $\begin{array}{l}\text { Intervention } 477 \\
\text { Control } 430\end{array}$ & Not reported & $\begin{array}{l}1 \text { season, } \\
42 \text { weeks }\end{array}$ & $\begin{array}{l}\text { Intervention } 23 \\
\text { Control } 30\end{array}$ & $\begin{array}{l}\text { No significant difference was } \\
\text { observed in time to groin injury, } \\
31 \% \text { of risk reduction not } \\
\text { significant (HR=0.69, } p=0.18 \text { ) }\end{array}$ \\
\hline Soderman et $a l^{44}$ & $\begin{array}{l}\text { Football, female (age } \\
\text { mean } 20.4 \\
\text { intervention } 20.5 \\
\text { control) }\end{array}$ & Balance board training. $10-15 \mathrm{~min}$ of home training & $\begin{array}{l}\text { Intervention } 62 \\
\text { Control } 78\end{array}$ & $\begin{array}{l}\text { Performed on an average } 65 \pm 19 \\
\text { times out of how many prescribed } \\
\text { ( } \geq 70 \text { times, } 30 \text { in preseason, } 3 \times \\
\text { week in a } 7 \text { months season) }\end{array}$ & $\begin{array}{l}1 \text { season, } \\
7 \text { months }\end{array}$ & $\begin{array}{l}\text { Intervention } 1 \\
\text { Control } 0\end{array}$ & Not reported for groin injury \\
\hline Steffen et $a l^{41}$ & $\begin{array}{l}\text { Football, adolescent, } \\
\text { young female } \\
(13-17)\end{array}$ & $\begin{array}{l}\text { 'The } 11 \text { ': } 10 \text { exercises for core stability, lower } \\
\text { extremity strength and neuromuscular control and } \\
\text { agility. } 10-15 \text { min warm-up programme during } \\
\text { regular practise }\end{array}$ & $\begin{array}{l}\text { Intervention } 1073 \\
\text { Control } 947\end{array}$ & $\begin{array}{l}\text { Average player completed } \\
\text { approximately } 15 \text { sessions. Once a } \\
\text { week after } 15 \text { consecutive sessions in } \\
\text { an } 8 \text { months season were prescribed }\end{array}$ & $\begin{array}{l}1 \text { season, } \\
8 \text { months }\end{array}$ & $\begin{array}{l}\text { Intervention } 6 \\
\text { Control } 14\end{array}$ & $\begin{array}{l}\text { No significant difference was } \\
\text { observed in the number of groin } \\
\text { injuries. Rate ratio } 0.4 \text { (Cl } 0.2 \\
\text { to 1.1) }\end{array}$ \\
\hline Wedderkopp et $a l^{45}$ & $\begin{array}{l}\text { Handball, young } \\
\text { female (16-18) }\end{array}$ & $\begin{array}{l}\text { Ankle disk practise and functional activities for both } \\
\text { lower and upper extremities. 10-15 min during } \\
\text { training sessions }\end{array}$ & $\begin{array}{l}\text { Intervention } 111 \\
\text { Control } 126\end{array}$ & Not reported & $\begin{array}{l}1 \text { season, } \\
10 \text { months }\end{array}$ & $\begin{array}{l}\text { Intervention } 0 \\
\text { Control } 0\end{array}$ & Not reported for groin injury \\
\hline
\end{tabular}


different in nature. Furthermore, groin injuries in women seem to be more related to hip joint and hip flexors, ${ }^{12}$ and significant differences in kinematics and muscle activation have been identified between genders during single-leg actions or cutting manoeuvres. ${ }^{50-53}$ It may be that women could obtain a better effect from preventive interventions focused on lower extremity alignment and neuromuscular control, as suggested by a possible large reduction in groin injuries among women, when initiating balance and coordination type exercises. Among male football players, groin injuries are often related to the hip adductor muscle group, ${ }^{10} 12$ and hip adduction weakness seems to be a significant risk factor in this group of athletes. ${ }^{23}{ }^{24}$ Considering apparent hip strength ${ }^{54}$ and coordination differences ${ }^{50-53}$ between men and women, it seems relevant to consider in the future whether groin prevention approaches must be specifically adapted to sex in the future.

Type of preventive programme

A non-significant risk reduction of 32\% (RR 0.68; 95\% CI 0.40 to 1.14) in the number of groin injuries was identified in the subgroup analysis on type of preventive programme. The potential preventive effect of 'The 11' programme in reducing the risk of groin injuries in female football players was recently highlighted in a systematic review. ${ }^{55}$ However, a revised

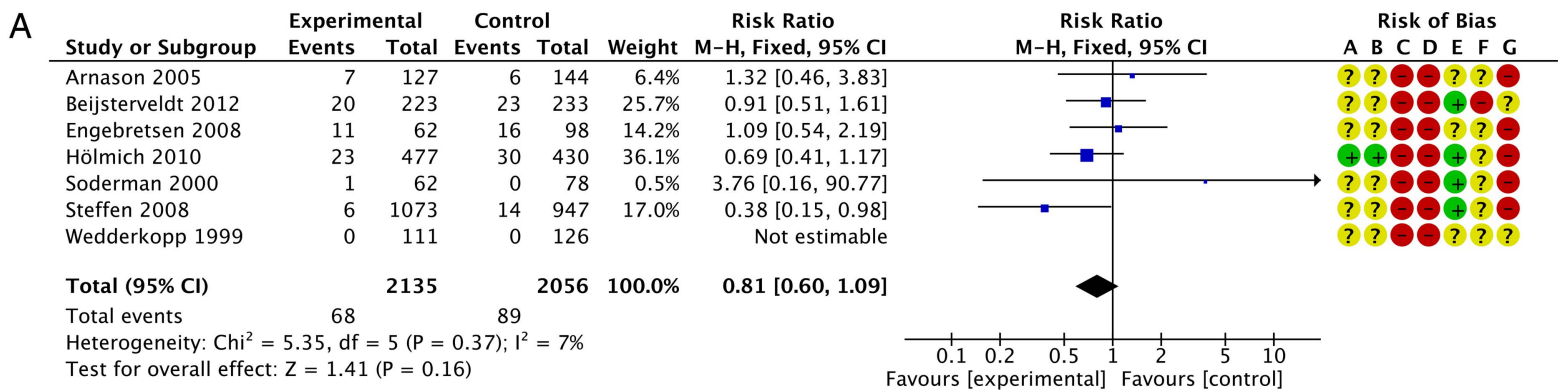

Risk of bias legend

(A) Random sequence generation (selection bias)

(B) Allocation concealment (selection bias)

(C) Blinding of participants and personnel (performance bias)

(D) Blinding of outcome assessment (detection bias)

(E) Incomplete outcome data (attrition bias)

(F) Selective reporting (reporting bias)

(G) Other bias

B

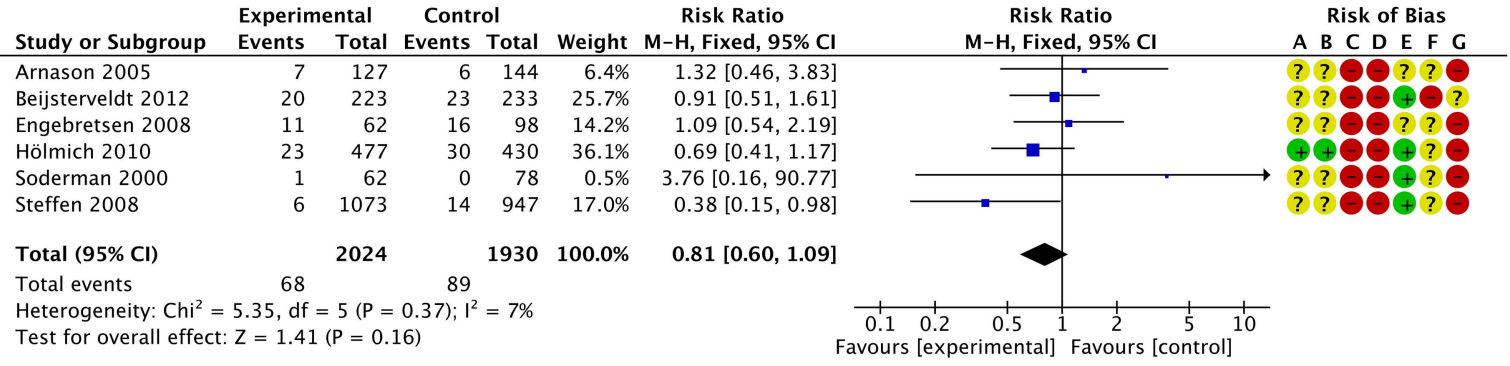

Risk of bias legend

(A) Random sequence generation (selection bias)

(B) Allocation concealment (selection bias)

(C) Blinding of participants and personnel (performance bias)

(D) Blinding of outcome assessment (detection bias)

(E) Incomplete outcome data (attrition bias)

(F) Selective reporting (reporting bias)

(G) Other bias

\begin{tabular}{|c|c|c|c|c|c|}
\hline \multirow[b]{2}{*}{ Study or Subgroup } & \multicolumn{2}{|c|}{ Experimental } & \multicolumn{2}{|c|}{ Control } & \multirow[b]{2}{*}{ Weigh } \\
\hline & Events & Total & Events & Total & \\
\hline Beijsterveldt 2012 & 20 & 223 & 23 & 233 & 33.9 \\
\hline Engebretsen 2008 & 11 & 62 & 16 & 98 & 18.7 \\
\hline Hölmich 2010 & 23 & 477 & 30 & 430 & 47. \\
\hline Total $(95 \% \mathrm{Cl})$ & & 762 & & 761 & 100 \\
\hline \multicolumn{6}{|c|}{$\begin{array}{l}\text { Heterogeneity: } \mathrm{Chi}^{2}=1.12, \mathrm{df}=2(\mathrm{P}=0.57) ; \mathrm{I}^{2}=0 \% \\
\text { Test for overall effect: } Z=1.02(P=0.31)\end{array}$} \\
\hline $\begin{array}{l}\text { Risk of bias legend } \\
\text { (A) Random sequenc } \\
\text { (B) Allocation conce } \\
\text { (C) Blinding of partic } \\
\text { (D) Blinding of outcc } \\
\text { (E) Incomplete outco } \\
\text { (F) Selective reportin } \\
\text { (G) Other bias }\end{array}$ & $\begin{array}{l}\text { generati } \\
\text { ment (se } \\
\text { pants and } \\
\text { ne asses } \\
\text { he data (a } \\
\text { (reportir }\end{array}$ & $\begin{array}{l}\mathrm{n} \text { (sele } \\
\text { ction b } \\
\text { person } \\
\text { ent (d } \\
\text { trition } \\
\text { bias) }\end{array}$ & $\begin{array}{l}\text { ction bias } \\
\text { ias) } \\
\text { nel (perfo } \\
\text { etection } \\
\text { bias) }\end{array}$ & $\begin{array}{l}\text { rmanc } \\
\text { oias) }\end{array}$ & bias) \\
\hline
\end{tabular}

Figure 2 (A) Primary analysis including all seven studies. (B) Subgroup analysis based on type of sport. (C) Subgroup analysis based on gender (only women). (D) Subgroup analysis based on gender (only men). (E) Subgroup analysis based on type of preventative programme (active adductor strength programme). (F) Subgroup analysis based on type of preventative programme ('The 11'). 


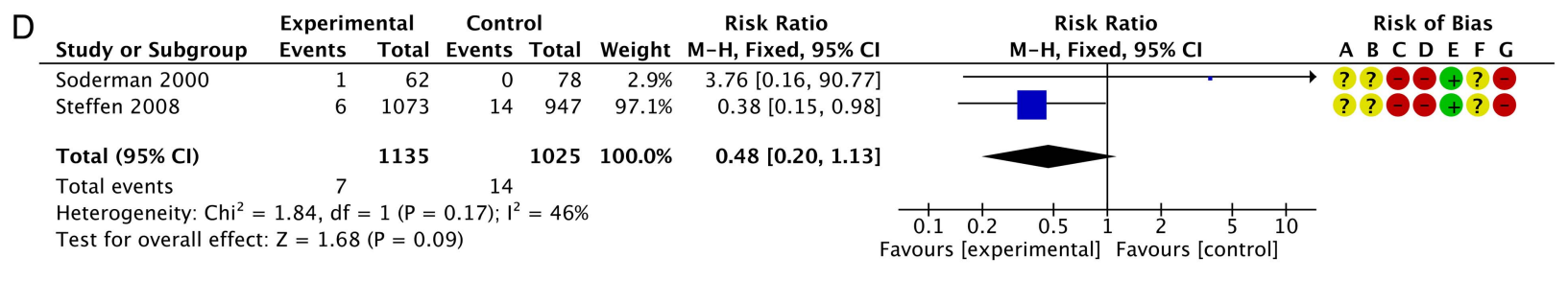

Risk of bias legend

(A) Random sequence generation (selection bias)

(B) Allocation concealment (selection bias)

(C) Blinding of participants and personnel (performance bias)

(D) Blinding of outcome assessment (detection bias)

(E) Incomplete outcome data (attrition bias)

(F) Selective reporting (reporting bias)

(G) Other bias

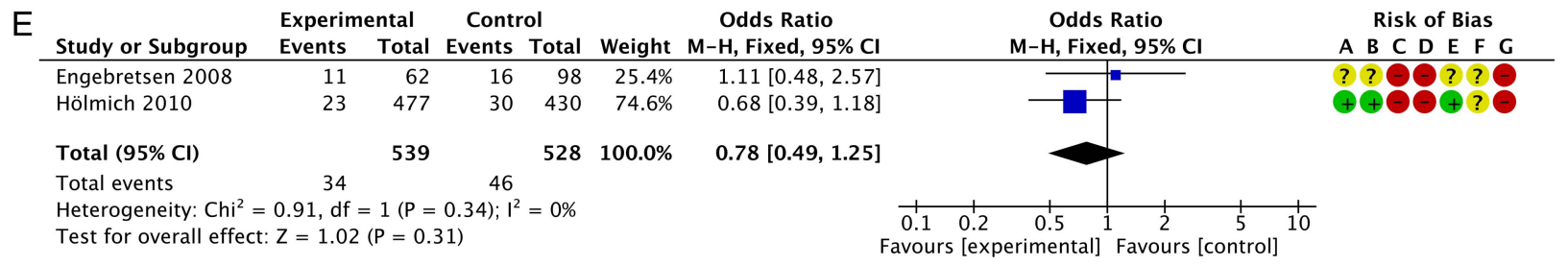

Risk of bias legend

(A) Random sequence generation (selection bias)

(B) Allocation concealment (selection bias)

(C) Blinding of participants and personnel (performance bias)

(D) Blinding of outcome assessment (detection bias)

(E) Incomplete outcome data (attrition bias)

(F) Selective reporting (reporting bias)

(G) Other bias

\begin{tabular}{|c|c|c|c|c|c|c|c|c|}
\hline \multirow[b]{2}{*}{ Study or Subgroup } & \multicolumn{2}{|c|}{ Experimental } & \multicolumn{2}{|c|}{ Control } & \multirow[b]{2}{*}{ Weight } & \multirow{2}{*}{$\begin{array}{c}\text { Odds Ratio } \\
\text { M-H, Fixed, } 95 \% \mathrm{Cl}\end{array}$} & \multirow{2}{*}{$\begin{array}{c}\text { Odds Ratio } \\
\text { M-H, Fixed, 95\% Cl }\end{array}$} & Risk of Bias \\
\hline & Events & Total & Events & Total & & & & A B C D E F G \\
\hline Beijsterveldt 2012 & 20 & 223 & 23 & 233 & $58.1 \%$ & $0.90[0.48,1.69]$ & & ? ? \\
\hline Steffen 2008 & 6 & 1073 & 14 & 947 & $41.9 \%$ & $0.37[0.14,0.98]$ & & \\
\hline Total $(95 \% \mathrm{Cl})$ & & 1296 & & 1180 & $100.0 \%$ & $0.68[0.40,1.14]$ & & \\
\hline Total events & 26 & & 37 & & & & & \\
\hline $\begin{array}{l}\text { Heterogeneity: } \mathrm{Chi}^{2} \\
\text { Test for overall effec }\end{array}$ & $\begin{array}{l}2.24, \mathrm{df} \\
\mathrm{Z}=1.46\end{array}$ & $\begin{array}{l}=1(P= \\
(P=0 .\end{array}$ & $\begin{array}{l}0.13) ; 1^{2} \\
14)\end{array}$ & $=55 \%$ & & & $\begin{array}{lll}1 & 1 & 1 \\
0.5 & 1 & 2\end{array}$ & \\
\hline
\end{tabular}

Risk of bias legend

(A) Random sequence generation (selection bias)

(B) Allocation concealment (selection bias)

(C) Blinding of participants and personnel (performance bias)

(D) Blinding of outcome assessment (detection bias)

(E) Incomplete outcome data (attrition bias)

(F) Selective reporting (reporting bias)

(G) Other bias

Figure 2 Continued.

programme, 'The 11+', including additional but very similar exercises to allow for variations and progressions, showed no effect on prevention of hip and groin injuries in young female football players. ${ }^{56}$ Further, in the same study, only 19 hip and groin injuries were included, in approximately 1900 players during a football season, suggesting that this problem is either minor or severely underreported, providing insufficient power to produce robust estimates on hip and groin injury preventative effects in this study. ${ }^{56}$

Pooled data for the effectiveness of adductor strength programmes in male football revealed a non-significant risk reduction of $22 \%$ (RR $0.78 ; 95 \%$ CI 0.49 to 1.25 ). Exercises in these interventions included concentric and eccentric adductor muscle contractions in coordination with abdominal muscles to target hip adductor weakness. ${ }^{23}$ We feel that the use of no or minimal equipment, such as elastic bands, progressing into more relevant contraction-specific exercise and positions, ${ }^{57} 58$ could be more beneficial for hip-adductor strengthening as a preventative measure in male football. ${ }^{24} 57$

\section{Risk of bias assessment}

In the risk of bias assessment, we considered the seven studies included at high risk of bias concerning blinding of participants and outcome assessors. In these types of preventive studies consisting of active interventions and subjective outcomes, true blinding is considered impossible. Further, the injuries were reported subjectively and participants were aware of the outcome. Thus, the outcome assessors were dependent on the subjective report, which theoretically could be influenced by study participants. Lastly, in five of the six included cluster randomised trials, insufficient information was reported and studies were considered as unclear on selection bias. Despite the fact that all seven studies included had several methodological aspects displaying high risk of bias, no obvious methodological differences in terms of blinding, concealment allocation, outcome definition or study designs, were present between studies. Therefore, we considered the seven studies included to be sufficiently homogeneous to allow for a meaningful meta-analysis, providing the best available evidence. 
Studies in the present review mainly included interventions based on active exercise strategies with the aim of improving hip/core strength, and/or lower limb balance and coordination exercises. ${ }^{40-45}$ The only study with a different approach was the study by Arnason $e t$ al, ${ }^{39}$ including a video-based awareness session in the respective clubs as a one-time intervention. Future studies may need to consider prevention strategies other than those aiming to improve hip/core strength and lower limb coordination. Regular physical screening and load monitoring in place of a sole preseason strategy have been suggested as a worthwhile strategy for early groin symptom identification and prevention. ${ }^{59-61}$ Future randomised controlled trial studies concerning early groin symptom identification and load management strategies are needed to investigate the effect of this kind of groin injury prevention strategy.

\section{Limitations}

More than 4000 players were included in the meta-analysis. However, the total number of injuries was very low (157 groin injuries in total). The outcome (groin injuries) in these studies was rare and large studies with at least 4000 players in each group are required to detect a $20 \%$ reduction in the number of groin injuries assuming that $8 \%$ of the players develop a groin injury. ${ }^{42}$ Unfortunately, all analyses in the present study are not sufficiently powered to statistically support the estimates provided, although they all suggest a reduced effect of different groin injury prevention strategies across different groups of athletes.

Owing to the lack of compliance reporting and specific definitions on compliant and non-compliant behaviour in the included studies, we believe that the estimates of the present study may, in fact, resemble the interventions' 'true' effectiveness (effect when applying intervention in real life), and not necessarily their efficacy (effect when applying intervention under controlled research conditions). ${ }^{62}$ Three of the included studies $^{39} 4245$ did not report information about compliance, and in the remaining four, ${ }^{40} 414344$ the participants did not perform the prescribed number of sessions. Above all, studies were not adjusted for compliance, meaning that the estimates are suggested to represent the intentions' effectiveness, and the efficacy of these interventions, at present, remains unknown.

An important limitation is that groin injury was not specifically defined in any of the included studies, and none of them reported the use of a standardised diagnostic protocol. Groin injury diagnosis is extremely challenging due to the possible multiple pathologies and overlapping symptoms. ${ }^{12}{ }^{63}$ It is known that the lack of consensus regarding injury definitions, diagnostic and standardised data collection procedures could influence the reported incidence of sports injuries. ${ }^{64}$ Importantly, in six of the seven included studies, a time-loss definition was used. ${ }^{39-41} 43-45$ When this definition is used one must take into account that minor injuries and/or especially overuse problems will not always be recorded. This will cause an underestimation of the total number of injuries. To avoid this problem, the use of questionnaires aimed at pain, function and sporting activity has been suggested for more detailed groin injury registration. ${ }^{65}$ The Copenhagen Hip and Groin Outcome Score (HAGOS) ${ }^{66}{ }^{67}$ has previously been validated in athletes with and without hip and/or groin pain and should be considered in future evaluations of preventive interventions for sportsrelated groin injuries.

\section{CONCLUSION}

Meta-analysis revealed a potential clinically meaningful groin injury reduction of $19 \%$, even though no statistical significant reduction in sport-related groin injuries could be documented. Insufficient statistical power from the included studies makes it difficult to provide firm conclusions on the effect of groin injury prevention.

\section{What are the new findings?}

- No statistical significant reduction in sport-related groin injuries could be documented.

- Estimates of groin injury reduction of $19-52 \%$ after implementing active groin injury prevention programmes, including specific exercise programmes, suggest that such an approach may be of clinical relevance and potentially worthwhile to consider in football players.

- Estimates concerning the efficacy of groin injury programmes in football are unknown as compliance and compliance reporting have been inadequately addressed in existing trials.

\section{Twitter Follow Ernest Esteve at @EsteveErnest}

Acknowledgements The authors would like to thank Mr Jordi Vicens Bordas for his assistance in completing this systematic review.

\section{Competing interests None.}

Provenance and peer review Not commissioned; externally peer reviewed.

\section{REFERENCES}

1 Renstrom P, Peterson L. Groin injuries in athletes. Br J Sports Med 1980;14:30-6.

2 Weiss BD. Nontraumatic injuries in amateur long distance bicyclists. Am J Sports Med 1985;13:187-92.

3 Grote K, Lincoln TL, Gamble JG. Hip adductor injury in competitive swimmers. Am J Sports Med 2004;32:104-8.

4 Paajanen $\mathrm{H}$, Ristolainen $\mathrm{L}$, Turunen $\mathrm{H}$, et al. Prevalence and etiological factors of sport-related groin injuries in top-level soccer compared to non-contact sports. Arch Orthop Trauma Surg 2011;131:261-6.

5 Lorentzon R, Wedren H, Pietila T. Incidence, nature, and causes of ice hockey injuries. A three-year prospective study of a Swedish elite ice hockey team. Am J Sports Med 1988;16:392-6.

6 Emery CA, Meeuwisse WH, Powell JW. Groin and abdominal strain injuries in the National Hockey League. Clin J Sport Med 1999;9:151-6.

7 Orchard J, Seward H. Epidemiology of injuries in the Australian Football League, seasons 1997-2000. Br J Sports Med 2002;36:39-44.

8 O'Connor D. Groin injuries in professional rugby league players: a prospective study. J Sports Sci 2004;22:629-36.

9 Werner J, Hagglund $M$, Walden $M$, et al. UEFA injury study: a propective study of hip and groin injuries in professional football over seven consecutive seasons. $\mathrm{Br} \mathrm{J}$ Sports Med 2009;43:1036-40.

10 Holmich P, Thorborg K, Dehlendorff $C$, et al. Incidence and clinical presentation of groin injuries in sub-elite male soccer. Br J Sports Med 2014;48:1245-50.

11 Emery CA, Meeuwisse WH. Risk factors for groin injuries in hockey. Med Sci Sports Exerc 2001;33:1423-33.

12 Holmich P. Long-standing groin pain in sportspeople falls into three primary patterns, a "clinical entity" approach: a prospective study of 207 patients. Br J Sports Med 2007;41:247-52; discussion 52.

$13 \mathrm{Sim}$ FH, Chao EY. Injury potential in modern ice hockey. Am J Sports Med 1978;6:378-84

14 Charnock BL, Lewis CL, Garrett WE Jr, et al. Adductor longus mechanics during the maximal effort soccer kick. Sports Biomech 2009;8:223-34.

15 Hägglund $M$, Waldén $M$, Ekstrand J. Injuries among male and female elite football players. Scand J Med Sci Sports 2009;19:819-27.

16 Karlsson MK, Dahan R, Magnusson H, et al. Groin pain and soccer players: male versus female occurrence. I Sports Med Phys Fitness 2014;54:487-93.

17 Arnason A, Sigurdsson SB, Gudmundsson A, et al. Risk factors for injuries in football. Am J Sports Med 2004;32(1 Suppl):5s-16s.

18 Thorborg K, Serner A, Petersen J, et al. Hip adduction and abduction strength profiles in elite soccer players: implications for clinical evaluation of hip adductor muscle recovery after injury. Am J Sports Med 2011;39:121-6. 
19 Hanna CM, Fulcher ML, Elley CR, et al. Normative values of hip strength in adult male association football players assessed by handheld dynamometry. I Sci Med Sport 2010;13:299-303.

20 Tyler TF, Silvers HJ, Gerhardt MB, et al. Groin injuries in sports medicine. Sports health 2010;2:231-6.

21 Ryan J, Deburca N, Mc Creesh K. Risk factors for groin/hip injuries in field-based sports: a systematic review. Br J Sports Med 2014;48:1089-96.

22 Tyler TF, Nicholas SJ, Campbell RJ, et al. The association of hip strength and flexibility with the incidence of adductor muscle strains in professional ice hockey players. Am J Sports Med 2001;29:124-8.

23 Engebretsen AH, Myklebust G, Holme I, et al. Intrinsic risk factors for groin injuries among male soccer players: a prospective cohort study. Am J Sports Med 2010;38:2051-7.

24 Thorborg K, Branci S, Nielsen MP, et al. Eccentric and isometric hip adduction strength in male soccer players with and without adductor-related groin pain: an assessor-blinded comparison. Orthop J Sports Med 2014;22.

25 Nicholas SJ, Tyler TF. Adductor muscle strains in sport. Sports Med 2002;32:339-44.

26 Dallinga JM, Benjaminse A, Lemmink KA. Which screening tools can predict injury to the lower extremities in team sports?: a systematic review. Sports Med 2012;42:791-815.

27 Maffey L, Emery C. What are the risk factors for groin strain injury in sport? A systematic review of the literature. Sports Med 2007;37:881-94.

28 Holmich P, Uhrskou P, Ulnits L, et al. Effectiveness of active physical training as treatment for long-standing adductor-related groin pain in athletes: randomised trial. Lancet 1999;353:439-43.

29 Tyler TF, Nicholas SJ, Campbell RJ, et al. The effectiveness of a preseason exercise program to prevent adductor muscle strains in professional ice hockey players. $\mathrm{Am} \mathrm{J}$ Sports Med 2002;30:680-3.

30 van Beijsterveldt AM, Krist MR, Schmikli SL, et al. Effectiveness and cost-effectiveness of an injury prevention programme for adult male amateur soccer players: design of a cluster-randomised controlled trial. Inj Prev 2011;17:e2.

31 Lynch SA, Renstrom PA. Groin injuries in sport: treatment strategies. Sports Med 1999:28:137-44

32 Moher D, Liberati A, Tetzlaff J, et al.; PRISMA Group. Preferred reporting items for systematic reviews and meta-analyses: the PRISMA statement. Int I Surg 2010;8:336-41.

33 Higgins JPT, Green S, eds. Cochrane handbook for systematic reviews of interventions version 5.1.0 [updated March 2011]. The Cochrane Collaboration, 2011. http://www.cochrane-handbook.org

34 Jüni $P$, Altman DG, Egger M. Systematic reviews in health care: assessing the quality of controlled clinical trials. BMJ 2001;323:42-6.

35 Higgins JP, Thompson SG, Deeks JJ, et al. Measuring inconsistency in meta-analyses. BMJ 2003;327:557-60.

36 Greenland S, Robins JM. Estimation of a common effect parameter from sparse follow-up data. Biometrics 1985;41:55-68.

37 Mantel N, Haenszel W. Statistical aspects of the analysis of data from retrospective studies of disease. J Nat/ Cancer Inst 1959;22:719-48.

38 Altman DG, Bland JM. Interaction revisited: the difference between two estimates. BMJ 2003;326:219.

39 Arnason A, Engebretsen L, Bahr R. No effect of a video-based awareness program on the rate of soccer injuries. Am J Sports Med 2005;33:77-84.

40 Engebretsen $\mathrm{AH}$, Myklebust $\mathrm{G}, \mathrm{Holme}$ l, et al. Prevention of injuries among male soccer players: a prospective, randomized intervention study targeting players with previous injuries or reduced function. Am J Sports Med 2008:36:1052-60.

41 Steffen K, Myklebust G, Olsen OE, et al. Preventing injuries in female youth football —a cluster-randomized controlled trial. Scand J Med Sci Sports 2008;18:605-14.

42 Holmich $\mathrm{P}$, Larsen K, Krogsgaard K, et al. Exercise program for prevention of groin pain in football players: a cluster-randomized trial. Scand J Med Sci Sports 2010;20:814-21.

43 van Beijsterveldt AM, van de Port IG, Krist MR, et al. Effectiveness of an injury prevention programme for adult male amateur soccer players: a cluster-randomised controlled trial. Br J Sports Med 2012;46:1114-18.

44 Söderman K, Werner S, Pietilö T, et al. Balance board training: prevention of traumatic injuries of the lower extremities in female soccer players?: A prospective randomized intervention study. Knee Surg Sports Traumatol Arthrosc 2000;8:356-63.
45 Wedderkopp N, Kaltoft M, Lundgaard B, et al. Prevention of injuries in young female players in European team handball. A prospective intervention study. Scand J Med Sci Sports 1999;9:41-7.

46 Holmich P, Nyvold P, Larsen K. Continued significant effect of physical training as treatment for overuse injury: 8 - to 12 -year outcome of a randomized clinical trial. Am J Sports Med 2011;39:2447-51.

47 Soligard T, Nilstad A, Steffen K, et al. Compliance with a comprehensive warm-up programme to prevent injuries in youth football. Br J Sports Med 2010;44:787-93.

48 Hagglund $M$, Atroshi I, Wagner $\mathrm{P}$, et al. Superior compliance with a neuromuscular training programme is associated with fewer $A C L$ injuries and fewer acute knee injuries in female adolescent football players: secondary analysis of an RCT. $\mathrm{Br}$ J Sports Med 2013;47:974-9.

49 Reilly K, Lovejoy B, Williams R, et al. Differences between a supervised and independent strength and conditioning program with chronic low back syndromes. J Occup Med 1989;31:547-50.

50 Zeller BL, McCrory JL, Kibler WB, et al. Differences in kinematics and electromyographic activity between men and women during the single-legged squat. Am J Sports Med 2003;31:449-56.

51 Pollard CD, Davis IM, Hamill J. Influence of gender on hip and knee mechanics during a randomly cued cutting maneuver. Clin Biomech (Bristol, Avon) 2004;19:1022-31.

52 Hanson AM, Padua DA, Troy Blackburn J, et al. Muscle activation during side-step cutting maneuvers in male and female soccer athletes. J Athl Train 2008;43:133-43.

53 Dwyer MK, Boudreau SN, Mattacola CG, et al. Comparison of lower extremity kinematics and hip muscle activation during rehabilitation tasks between sexes. J Athl Train 2010;45:181-90.

54 Thorborg K, Bandholm T, Holmich P. Men are stronger than women-also in the hip. J Sci Med Sport 2013;16:E1-3.

55 Herman K, Barton C, Malliaras P, et al. The effectiveness of neuromuscular warm-up strategies, that require no additional equipment, for preventing lower limb injuries during sports participation: a systematic review. BMC Med 2012;10:75.

56 Soligard T, Myklebust G, Steffen K, et al. Comprehensive warm-up programme to prevent injuries in young female footballers: cluster randomised controlled trial. BMJ 2009:338:95-9.

57 Jensen J, Holmich P, Bandholm T, et al. Eccentric strengthening effect of hip-adductor training with elastic bands in soccer players: a randomised controlled trial. Br J Sports Med 2014;48:332-8.

58 Serner A, Jakobsen MD, Andersen LL, et al. EMG evaluation of hip adduction exercises for soccer players: implications for exercise selection in prevention and treatment of groin injuries. Br J Sports Med 2014;48:1108-14.

59 Paul DJ, Nassis GP, Whiteley R, et al. Acute responses of soccer match play on hip strength and flexibility measures: potential measure of injury risk. J Sports Sci 2014;32:1318-23.

60 Pizzari T, Coburn PT, Crow JF. Prevention and management of osteitis pubis in the Australian Football League: a qualitative analysis. Phys Ther Sport 2008;9:117-25.

61 Crow JF, Pearce AJ, Veale JP, et al. Hip adductor muscle strength is reduced preceding and during the onset of groin pain in elite junior Australian football players. J Sci Med Sport 2010;13:202-4.

62 Glasgow RE, Lichtenstein E, Marcus AC. Why don't we see more translation of health promotion research to practice? Rethinking the efficacy-to-effectiveness transition. Am J Public Health 2003;93:1261-7.

63 Jansen JA, Mens JM, Backx FJ, et al. Diagnostics in athletes with long-standing groin pain. Scand J Med Sci Sports 2008;18:679-90.

64 Junge A, Dvorak J. Influence of definition and data collection on the incidence of injuries in football. Am J Sports Med 2000;28(suppl 5):S40-6.

65 Clarsen B, Myklebust G, Bahr R. Development and validation of a new method for the registration of overuse injuries in sports injury epidemiology: the Oslo Sports Trauma Research Centre (OSTRC) overuse injury questionnaire. Br J Sports Med 2013:47:495-502.

66 Thorborg K, Holmich P, Christensen R, et al. The Copenhagen Hip and Groin Outcome Score (HAGOS): development and validation according to the COSMIN checklist. Br J Sports Med 2011;45:478-91.

67 Thorborg K, Branci S, Stensbirk F, et al. Copenhagen hip and groin outcome score (HAGOS) in male soccer: reference values for hip and groin injury-free players. $\mathrm{Br} J$ Sports Med 2014;48:557-9. 